\title{
GAMBARAN KESINTASAN PASIEN KO-INFEKSI TB-HIV BERDASARKAN LOKASI ANATOMI TUBERKULOSIS DI RUMAH SAKIT PENYAKIT INFEKSI PROF. DR. SULIANTI SAROSO TAHUN 2010-2013
}

\author{
Nor Efendi ${ }^{1}$, Helda $^{1}$,Tri Yunis Miko Wahyono ${ }^{1}$, Titi Sundari ${ }^{2}$ \\ ${ }^{1}$ Departemen Epidemiologi, Fakultas Kesehatan Masyarakat, Universitas Indonesia \\ ${ }^{2}$ SMF Paru Rumah Sakit Penyakit Infeksi Prof. Dr. Sulianti Sarosos Jakarta
}

\begin{abstract}
Abstrak : Penelitian ini bertujuan untuk mengetahui gambaran kesintasan 2 tahun setelah diagnosis pasien koinfeksi TB-HIV berdasarkan lokasi anatomi Tuberkulosis (TB). Penelitian ini menggunakan desain kohort restrospektif dinamik menggunakan 177 rekam medik pasien ko-infeksi TB-HIV di RSPI Prof. Dr Sulianti Saroso Jakarta yang terdaftar tahun 2010-2013, diambil secara simple random sampling Kesintasan pasien ko-infeksi TB-HIV 2 tahun setelah diagnosa dengan lokasi anatomi TB di ekstra paru sebesar $86 \%$, lebih rendah dibandingkan dengan lokasi anatomi TB di paru sebesar 98\%. Lokasi anatomi TB di ekstra paru beresiko lebih cepat mengalami kematian pada pasien ko-infeksi TB-HIV (HR 1,47, 95\% Cl : 0,55-3,90). Infeksi HIV mengakibatkan kerusakan sistem imunitas tubuh yang luas sehingga infeksi dan penyebaran kuman TB juga akan meluas seperti ke kelenjar getah bening, pleura dan organ lainnya. TB ekstra paru memiliki beban bakteri TB yang lebih tinggi dan menunjukkan progresifitas perjalanan penyakit semakin parah yang mengakibatkan probabilitas ketahanan hidup (kesintasan) penderitanya semakin menurun. Perlu dilakukan screening lebih intensif terhadap pasien ko-infeksi TB-HIV untuk menemukan kemungkinan TB di ekstra paru sedini mungkin agar dapat diberikan penatalaksanaan yang tepat dalam rangka meningkatkan kualitas hidup penderitanya.
\end{abstract}

Kata Kunci : Lokasi Anatomi TB; Kesintasan; Ko-infeksi TB-HIV

\section{THE SURVIVAL OVERVIEW OF TB-HIV CO-INFECTION PATIENS BASED ON THE ANATOMICAL SITE OF TUBERCULOSIS IN INFECTIOUS DISEASE HOSPITAL PROF DR SULIANTI SAROSO (2010-2013)}

\begin{abstract}
The study aims to describe the overview of survival for 2 years after diagnosed of patients co-infection with TB-HIV based on the anatomical site of Tuberculosis (TB). The design of this study was dynamic retrospective cohort with 177 medical records of TB-HIV co-infection patients in the Center of infection hospital Prof. Dr. Sulianti Saroso, Jakarta, from 2010 to 2013, taken by simple random sampling technique. The survival of TB-HIV co-infection for 2 years after it was diagnosed in patients with anatomical site of TB in the extrapulmonary was $86 \%$ and it was lower compared to patient with the anatomical site in the pulmonary which was 98\%. Anatomical site of TB in the extrapulmonary had risk of death faster toward TB-HIV co-infection patients (HR 1,47, 95\% Cl:0,55-3,90). HIV infection cause the widespreading damage in the immunity system therefor the infection of TB microbe also spreading to other organ such as lymph nodes and pleura. Extrapulmonary TB has much more TB microbe that worsen the progressivity of the disease and decrease the probability of the patient's survival. Intensive screening are needed for TB/HIV co-infection patients to diagnosed the possibility of TB infection in the extrapulmonary as early as possible to increase the quality of life of its patients by finding the proper treatment.
\end{abstract}

Keywords : TB anatomical site; survival; TB-HIV co-infection

Korespondensi :

Nor Efendi

Departemen Epidemiologi, Gd.A Lt.1, Fakultas

Kesehatan Masyarakat, Universitas Indonesia, HP : 082250206161

Email : nanang_bjm2001@yahoo.co.id

\section{PENDAHULUAN}

Infeksi HIV dikaitkan tidak hanya dengan peningkatan kejadian TB, tetapi juga dengan perubahan manifestasi klinis terutama pada tahap lanjut dimana terjadi penyebarluasan kuman TB. Pada orang 
dengan infeksi TB laten akan lebih berisiko untuk berkembang menjadi TB aktif ketika mereka terinfeksi HIV ${ }^{17}$.

Ketika HIV berkembang maka jumlah dan fungsi limfosit-T CD4 menurun. Selsel ini mempunyai peran yang penting untuk melawan kuman TB. Dengan demikian, sistem kekebalan tubuh menjadi kurang mampu untuk mencegah perkembangan dan penyebaran lokal kuman ini. TB ekstraparu dan diseminata (meluas) menjadi lebih lazim ditemukan. TB ekstraparu yang paling sering ditemukan adalah efusi pleura, limpadenopati, penyakit perikardium, milier, meningitis, TB diseminata dengan mikobakteriemia ${ }^{4}$.

Banyaknya kematian pada pasien HIV positif dengan TB Paru BTA negatif mungkin berhubungan dengan beberapa faktor, terutama penurunan imunitas terkait rendahnya CD4. Sedangkan kematian pada pasien TB ekstra paru terkait dengan kurangnya sumber daya sehingga menyebabkan tingginya kesalahan diagnostik yang menyebabkan meningkatnya morbiditas dan mortalitas. Hal ini juga dihubungkan dengan kekeliruan menempatkan semua pasien TB paru sebagai stadium 3 berdasarkan kriteria WHO, sehingga menyebabkan TB paru BTA negatif yang sebenarnya memiliki prognosis yang jauh lebih buruk dan seharusnya dimasukkan sebagai stadium 4 bersama dengan TB ekstra paru agar mendapat penanganan yang lebih intensif dari pada TB paru BTA positif ${ }^{12}$.

TB merupakan infeksi oportunistik terbanyak pada ODHA. Infeksi HIV mengakibatkan penurunan imunitas tubuh yang progresif, sehingga infeksi TB laten akan cenderung berkembang menjadi TB aktif serta penyebaran kuman TB yang meluas tidak mampu dicegah oleh sistem imunitas tubuh. TB ekstraparu dan diseminata (meluas) menjadi lebih lazim terjadi serta membuat prognosis menjadi lebih buruk.

World Health Organization (WHO) pada tahun 2013 memperkirakan dari 9 juta orang yang terinfeksi Tuberkulosis (TB), 1.1 juta (13\%) diantaranya juga terinfeksi Human Immunodeficiency
Virus ${ }^{1}$. Tingkat ko-infeksi TB-HIV dari orang-orang dengan hasil tes HIV positif di 41 negara dengan beban TB dan HIV tinggi berada dikisaran 18-20\%. Persentasi tertinggi berada di wilayah Afrika sekitar $41 \%$, sedangkan di Asia Tenggara sekitar $6 \%$. Indonesia menempati peringkat terendah dalam hal cakupan pasien TB dengan hasil tes HIV diketahui, yaitu hanya sekitar $2 \%^{2}$. Perkiraan WHO tentang jumlah pasien TB dengan status HIV positif di Indonesia pada tahun 2013 sekitar 7,5\% yang meningkat cukup signifikan dibandingkan tahun 2012 yang hanya $3,3 \%{ }^{(3)}$. TB masih dilaporkan sebagai sebagai infeksi oportunistik (IO) terbanyak pada ODHA yaitu sebesar $49 \%$ pada tahun $2010^{4}$, meskipun persentasinya sedikit menurun pada tahun 2013 menjadi 39,48\% dari seluruh ko-infeksi dan pada tahun 2014 (sampai akhir September) sebanyak $28,04 \% 5$.

TB juga merupakan penyebab kematian utama pada ODHA. termasuk pada mereka yang telah mendapat Anti Retroviral Terapi (ART). Jumlah kematian TB yang terkait HIV meskipun telah menurun sejak tahun 2004 yang diperkirakan sekitar 540.000, namun secara global masih tercatat sekitar 360.000 pada akhir tahun 2013, setara $25 \%$ dari seluruh kematian TB dan sekitar $25 \%$ dari perkiraan 1,5 juta kematian akibat HIV/AIDS ${ }^{2}$. TB merupakan penyebab kematian pada $39.3 \%$ pasien ko-infeksi TB-HV yang menjalani pengobatan di Thailand ${ }^{6}$. Penelitian di Tanzania membuktikan bahwa pada kelompok pengidap HIV dengan TB akan 4.7 kali $(95 \% \mathrm{Cl}: 1.63-13.05)$ lebih cepat untuk mengalami kematian di bandingkan dengan kelompok pengidap HIV tanpa $\mathrm{TB}^{(7)}$, sedangkan penelitian di Indonesia mendapatkan hazard ratio yang lebih kecil dimana pasien HIV/AIDS dengan TB hanya 1.6 kali $(95 \% \mathrm{Cl}: 0.96-2.67)$ lebih cepat untuk mengalami kematian dibandingkan pasien HIV/AIDS tanpa TB ${ }^{8}$.

Kematian penderita TB pada ODHA sekitar $40-50 \%$ terutama pada TB paru dengan hasil pemeriksaan Bakteri Tahan Asam (BTA) negatif dan TB ekstra paru yang kemungkinan disebabkan karena 
keterlambatan diagnosis dan terapi $\mathrm{TB}^{4}$. Penelitian di Brazil menyimpulkan bahwa kombinasi TB paru dan ekstra paru 8.2 $(95 \% \mathrm{Cl}: 6.2-10.8)$ kali lebih sering terjadi pada pasien TB dengan AIDS dibandingkan dengan pasien TB tanpa AIDS'. Penelitian lainnya yang membandingkan kematian pasien koinfeksi TB-HIV berdasarkan lokasi anatomi TB menyimpulkan bahwa pada kombinasi TB paru dan ekstra paru akan 1.87 kali $(95 \% \mathrm{Cl}: 1.12-3.13)$ lebih berisiko mengalami kematian dibandingkan dengan lokasi TB di ekstra paru atau di paru saja ${ }^{(10)}$. Penelitian di Kamerun yang mengamati kematian pasien ko-infeksi TBHIV selama masa pengobatan dengan Obat Anti Tuberkulosis (OAT) menyimpulkan bahwa pada kombinasi lokasi TB di paru dan ekstra paru akan 1.74 kali $(95 \% \mathrm{Cl}: 0.47-6.84)$ lebih berisiko mengalami kematian dibandingkan dengan lokasi TB yang hanya di paru atau ekstra paru saja ${ }^{11}$.

Penelitian-penelitian yang terkait dengan kesintasan pasien ko-infeksi TBHIV berdasarkan lokasi anatomi TB juga telah dilakukan di beberapa negara. Penelitian di Malawi mendapatkan risiko pasien ko-infeksi TB-HIV dengan lokasi ekstra paru untuk mendapatkan kematian setelah tujuh tahun pengamatan adalah sebesar $1.7(95 \% \quad \mathrm{Cl}:$ 1.3-2.0) kali, sedangkan pasien dengan TB paru BTA negatif sebesar 2.1 kali $(95 \% \mathrm{Cl}: 1.7-2.6)$ terhadap kelompok referen pasien dengan TB paru BTA positif ${ }^{12}$.

Penelitian lainnya di Kamboja menyimpulkan bahwa pada pasien koinfeksi TB-HIV yang telah mendapat Anti Retroviral Terapi (ART) dengan masa pengamatan rata-rata selama 25 bulan menyimpulkan bahwa pada kelompok pasien dengan TB diseminata (meluas) berisiko 2.55 kali $(95 \%$ Cl : 1.78-3.65) lebih cepat untuk mengalami kematian, dibandingkan dengan kelompok pasien dengan TB ekstraparu saja yang hanya 1.02 kali $(95 \%$ Cl : 0.52-2.01) berisiko lebih cepat mengalami kematian terhadap referen kelompok pasien dengan TB paru saja $^{13}$. Sedangkan penelitian di Ukraina yang membagi pasien ko-infeksi TB-HIV hanya berdasarkan 2 kelompok menemukan bahwa pada pasien dengan
TB ekstra paru akan berisiko 2.4 kali $(95 \%$ $\mathrm{Cl}: 1.2-10.4)$ lebih cepat untuk mengalami kematian dibandingkan dengan kelompok TB paru ${ }^{14}$.

Rumah Sakit Penyakit Infeksi Prof. Dr. Sulianti Saroso (RSPI-SS) adalah salah satu RS pusat kajian dan rujukan nasional penyakit infeksi, termasuk HIV/AIDS. RS yang berlokasi di Jakarta dimana merupakan provinsi dengan kasus HIV/AIDS terbanyak di Indonesia ini telah melayani pasien HIV/AIDS sejak tahun $1995^{15}$. Jumlah kumulatif ODHA yang tercatat dan dilayani di RSPI-SS cenderung meningkat yaitu pada tahun 2010 sebanyak 158 kasus, tahun 2011 sebanyak 163 kasus dan tahun 2012 sebanyak 238 kasus sedangkan tren kematian pada ODHA berfluktuasi yaitu sebanyak 8 kasus pada tahun 2010, 17 kasus pada tahun 2011 dan 13 kasus pada tahun $2012^{16}$.

Informasi tentang gambaran kesintasan (ketahanan hidup) pasien ko-infeksi TBHIV berdasarkan lokasi anatomi TB belum pernah dilakukan pada populasi di Indonesia. sehingga perlu dilakukan penelitian tentang hal ini untuk menjawab pertanyaan penelitian bagaimana gambaran kesintasan (ketahanan hidup) pasien ko-infeksi TB-HIV berdasarkan lokasi anatomi TB.

\section{METODE PENELITIAN}

Penelitian observasional dengan desain kohort retrospektif yang bersifat dinamis dimana subyek diidentifikasi saat mulai didiagnosis sebagai pasien koinfeksi TB-HIV kemudian diikuti selama 2 tahun masa pengamatan untuk melihat kesintasannya (ketahanan hidup). Masa pengamatan 2 tahun ditetapkan berdasarkan feasibility data dan waktu penelitian. Penelitian ini dilakukan di Rumah Sakit Penyakit Infeksi Prof. Dr. Sulianti Saroso Jakarta dengan waktu pengumpulan data dilaksanakan pada bulan April-Mei 2015. Penelitian ini bertujuan mengetahui gambaran kesintasan (ketahanan hidup) pasien koinfeksi TB-HIV berdasarkan lokasi anatomi TB di RSPI Prof. Dr. Sulianti Saroso Jakarta, pada tahun 2010-2013. Populasi penelitian adalah semua pasien ko-infeksi 
TB-HIV dengan kriteria inklusi pasien dewasa (usia $\geq 15$ tahun) yang terdaftar bulan Januari 2010-April 2013 dan kriteria ekslusi pasien yang hamil selama masa pengamatan atau dengan catatan rekam medik tentang variabel penelitian tidak lengkap maupun tidak ditemukan. Besar sampel minimal yang dibutuhkan dengan confident interval $95 \%$ dan power $90 \%$ adalah 40 orang per kelompok ${ }^{18}$. Sampel dipilih secara acak sederhana.

Sumber data yang digunakan dalam penelitian ini berasal dari rekam medik, register $A R V$, ikhtisar $A R V$ pasien, form TB.01 dan form/software elektronik TB. 03 pasien ko-infeksi TB-HIV. Penelusuran data melalui telepon juga dilakukan jika diperlukan. Penelitian ini telah lolos Ethical Clearance dari Komite Etik Rumah Sakit Penyakit Infeksi Prof. Dr. Sulianti Saroso Jakarta. Pengumpulan data dilakukan oleh enumerator yang di blind terhadap hipotesa penelitian.

Variabel independen adalah lokasi anatomi TB berdasarkan diagnosis dokter diklasifikasikan sebagai TB paru bila TB hanya menyerang jaringan (parenkim) paru saja, tidak termasuk pleura (selaput paru) dan TB ekstra paru bila TB menyerang organ tubuh lain selain paru seperti pleura, selaput otak, selaput jantung (perikardium), kelenjar limfe, tulang, persendian, kulit, usus, ginjal, saluran kencing, alat kelamin, dan lain-lain atau kombinasi TB yang menyerang paru dan ekstra paru secara bersamaan. Sedangkan variabel dependen adalah waktu yang dihitung sejak didiagnosa sebagai pasien ko-infeksi TB-HIV sampai terjadinya event berupa kematian atau sensor hingga akhir pengamatan. Pasien dikatakan sensor bila masih hidup dalam waktu 2 tahun masa pengamatan atau hilang dari pengamatan (pada tanggal kunjungan terakhir) hingga akhir penelitian $^{19}$.

Analisis secara univariat dan bivariat menggunakan analisis survival. Probabilitas kesintasan pasien ko-infeksi TB-HIV ditampilkan dalam bentuk kurva survival function.

\section{HASIL PENELITIAN:}

Tabel 1. Distribusi Frekuensi Subyek Berdasarkan Lokasi Anatomi TB Dan Status Event

\begin{tabular}{|c|c|c|c|c|c|c|c|}
\hline \multirow{3}{*}{ Variabel } & \multirow{3}{*}{ Kategori } & \multirow{2}{*}{\multicolumn{2}{|c|}{$\begin{array}{c}\begin{array}{c}\text { Meninggal } \\
\text { (Event) }\end{array} \\
\mathrm{n}=18 \\
(10,17 \%)\end{array}$}} & \multicolumn{2}{|c|}{ Sensor } & \multicolumn{2}{|c|}{ Total } \\
\hline & & & & \multicolumn{2}{|c|}{$\begin{array}{c}\mathrm{n}=159 \\
(89,83 \%)\end{array}$} & \multicolumn{2}{|c|}{$\begin{array}{c}n=177 \\
(100 \%)\end{array}$} \\
\hline & & $\mathrm{n}$ & $\%$ & $\mathrm{n}$ & $\%$ & $\mathrm{n}$ & $\%$ \\
\hline \multirow{2}{*}{ Lokasi Anatomi TB } & Paru & 12 & 9,1 & 120 & 90,9 & 132 & 74,6 \\
\hline & Ekstra Paru & 6 & 13,3 & 39 & 86,7 & 45 & 25,4 \\
\hline
\end{tabular}

Berdasarkan tabel distribusi frekuensi di atas diketahui bahwa dari 177 sampel penelitian didapatkan sebagian besar lokasi anatomi TB di paru yaitu 132 orang (74,6\%). Pada kelompok lokasi anatomi
TB di ekstra paru lebih banyak yang mengalami event (meninggal) sebesar $13,33 \%$ dibandingkan kelompok lokasi anatomi TB di paru yang mengalami event hanya $9,09 \%$.

Tabel 2. Distribusi Frekuensi TB Ekstra Paru Berdasarkan Lokasi

\begin{tabular}{lcc}
\multicolumn{1}{c}{ Lokasi TB Ekstra Paru } & $\mathrm{n}$ & $\%$ \\
\hline Limfadenitis TB & 41 & 91,11 \\
\hline Peritonitis TB & 2 & 4,44 \\
\hline Pleuritis TB & 2 & 4,44 \\
\hline & 45 & 100 \\
\hline
\end{tabular}


Berdasarkan tabel distribusi frekuensi di atas diketahui bahwa dari 45 orang subyek penelitian dengan lokasi anatomi
TB di ekstra paru, sebagian besar adalah yang berlokasi di limfe (limfadenitis TB) yaitu sebanyak 41 orang $(91,11 \%)$.

Tabel 3. Kesintasan Pasien Ko-infeksi TB-HIV Berdasarkan Lokasi Anatomi TB

\begin{tabular}{lcccccc}
\hline Lokasi Anatomi TB & $\begin{array}{c}\text { Prob. } \\
\text { Survival }\end{array}$ & Mean Survival & $\begin{array}{c}\text { Log } \\
\text { Rank }\end{array}$ & $H R$ & $95 \% \mathrm{Cl}$ & Nilai $p$ \\
\cline { 1 - 4 } & 0,98 & 686 & & & & \\
\cline { 1 - 4 } Paru & 0,440 & 1,47 & $0,55-3,90$ & 0,444 \\
\hline
\end{tabular}

Berdasarkan hasil analisis bivariat diketahui bahwa probabilitas survival 2 tahun (730 hari) pasien ko-infeksi TB-HIV dengan lokasi anatomi di paru sebesar 0,98 yang artinya kesintasan atau harapan untuk survive (bertahan hidup) adalah sebesar $98 \%$ dengan lama rata-rata adalah 686 hari. Sedangkan pada kelompok lokasi anatomi TB di ekstra paru probabilitas survival sebesar 0,86 yang artinya kesintasan atau harapan untuk survive (bertahan hidup) adalah sebesar $86 \%$ dengan lama rata-rata adalah 673 hari. Nilai hazard rate didapatkan 1,47 dengan $95 \% \mathrm{Cl}: 0,55-3,90$ dan nilai $p=$ 0,444 .

Di bawah ini adalah plot probabilitas survival (kesintasan) 2 tahun pasien koinfeksi TB-HIV secara kumulatif dan berdasarkan lokasi anatomi.

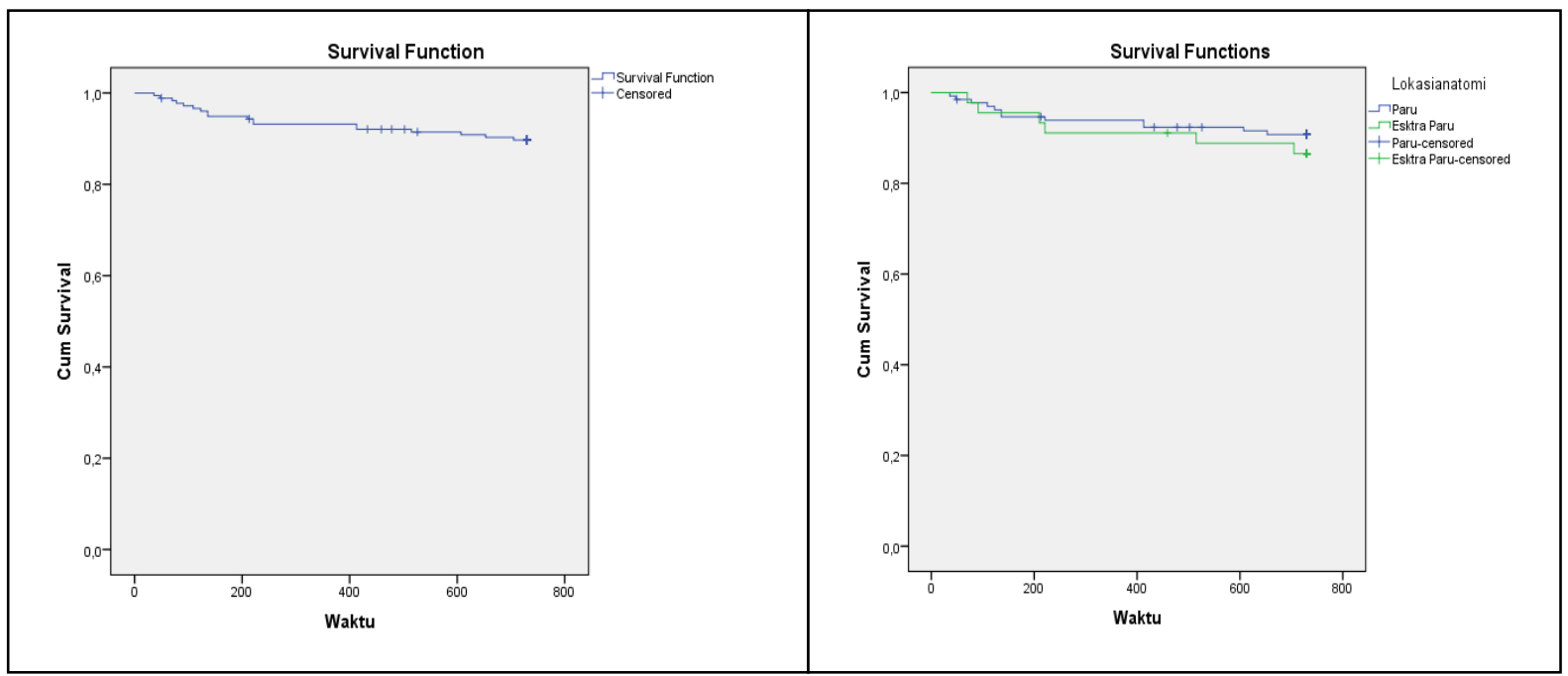

Gambar 2. Plot Survival (Kesintasan) 2 tahun Pasien Ko-infeksi TB-HIV secara kumulatif \& berdasarkan lokasi anatomi TB

\section{PEMBAHASAN}

Dalam penelitian ini terdapat beberapa keterbatasan yang mempengaruhi validitas hasil seperti bias informasi dan jumlah sampel. Keterbatasan penelitian retrospektif menggunakan data dari rekam medik yang diisi oleh pihak lain di masa lalu, kualitas pengukurannya tidak dapat dikontrol oleh peneliti sehingga kemungkinan bias informasi akibat pencatatan kurang lengkap atau akurat sesuai dengan definisi operasional penelitian bisa saja terjadi.

Status event berupa kematian pasien ko-infeksi TB-HIV pada penelitian ini yang hanya berjumlah $18(10,17 \%)$ dari 177 sampel merupakan kelemahan lainnya yang menyebabkan informasi median kesintasan tidak didapatkan karena jumlah subyek yang mengalami event tidak mencapai $50 \%$. Metode pengambilan 
sampel belum sepenuhnya dilakukan secara acak (random) karena mendahulukan kelengkapan data yang dibutuhkan peneliti sebagai bahan pertimbangan utama. Selain hal tersebut, rekam medik pasien ko-infeksi TB-HIV yang terekslude sebagai subyek penelitian karena tidak ditemukan lagi dalam arsip rumah sakit, jumlahnya cukup besar yaitu 75 (27,47\%) dari 273, sehingga kemungkinan juga mempengaruhi jumlah event yang masuk ke dalam populasi eligible penelitian. Rekam medis yang tidak ditemukan atau tidak lengkap tersebut sebagian besar adalah milik pasien inaktif yang telah meninggal atau pindah ke tempat pelayanan lain yang sebenarnya akan berkontribusi meningkatkan jumlah event dalam populasi penelitian.

Lokasi anatomi TB yang merupakan variabel independen penelitian ditetapkan berdasarkan lokasi organ tempat penyakit TB bersarang, diklasifikasikan sebagai paru dan ekstra paru. Menurut penelitian di Brazil menyimpulkan bahwa kombinasi TB paru dan ekstra paru $8.2(95 \% \mathrm{Cl}: 6.2-$ 10.8) kali lebih sering terjadi pada pasien TB dengan AIDS dibandingkan dengan pasien TB tanpa AIDS ${ }^{20}$. Penegakkan diagnosis TB pada penderita HIV tidak terlalu berbeda dengan bukan penderita HIV yang terutama berdasarkan hasil pemeriksaan mikroskopis dahak, namun pada ODHA dengan TB seringkali diperoleh hasil pemeriksaan dahak BTA negatif. Disamping itu, pada ODHA sering dijumpai TB ekstra paru dimana diagnosis pastinya ditegakkan dengan cara yang lebih rumit dan kompleks dibandingkan dengan TB paru, yaitu selain berdasarkan pemeriksaan klinis juga dengan pemeriksaan bakteriologis dan atau histopatologi dari organ tubuh yang terkena. Hal ini dapat menyebabkan bias informasi dimana bila dengan hasil pemeriksaan mikroskopis sederhana telah dapat didiagnosis TB paru, pemeriksaan lanjutan untuk mengetahui apakah juga terdapat TB ekstra paru (kombinasi TB paru dan ekstra paru) kemungkinan akan terabaikan. Penderita kombinasi TB paru dan ekstra paru dalam pencatatan dan pelaporan program TB nasional akan tercatat sebagai TB paru saja ${ }^{21}$.

Kesintasan pasien ko-infeksi TB-HIV dengan lokasi anatomi di paru lebih tinggi dari pada lokasi anatomi TB di ekstra paru dimana pada kelompok lokasi anatomi TB ekstra paru berisiko 1,47 kali untuk lebih cepat mengalami kematian dbandingkan kelompok lokasi anatomi TB paru, namun hasil ini tidak bermakna secara statistik $(p>0,005)$ serta dengan range nilai $95 \%$ confident interval $(\mathrm{Cl})$ yang cukup lebar dan melewati angka 1 (null value). Hal ini menunjukkan bahwa hubungan yang terjadi mungkin saja karena faktor kebetulan (chance), atau karena event yang tidak sering terjadi sehingga dibutuhkan subyek yang lebih banyak dari besar sampel minimal untuk dapat mengamati event dalam jumlah yang cukup ${ }^{22}$.

Hasil penelitian ini sesuai dengan penelitian di Kamboja yang juga mendapatkan hazard rate kematian pada pasien ko-infeksi TB-HIV dengan lokasi anatomi di ekstra paru sebesar 1,02 (95\% $\mathrm{Cl}:$ 0,52-2.01), sedangkan diseminata TB sebesar $2,55(95 \% \mathrm{Cl}: 1,78-2.01)$ yang bermakna signifikan secara statistik pada nilai kemaknaan 0,05 dengan nilai $p=$ $0,001 \quad(p<0,005)$. Penelitian tersebut melibatkan jumlah sampel yang lebih banyak yaitu 661 orang yang berasal dari 5 rumah sakit di Kamboja dengan pengamatan selama 50 minggu. Penelitian ini menggunakan protokol lembaga penelitian internasional yang mendanai dan mengawasi dengan ketat proses penelitian, sehingga kecil kemungkinan hasilnya dipengaruhi oleh berbagai macam bias yang bisa dikendalikan ${ }^{13}$.

Penelitian lain di Kamerun terhadap 337 subyek pasien ko-infeksi TB-HIV selama masa pengobatan dengan Obat Anti Tuberkulosis (OAT) yang diamati terhadap kematian menyimpulkan bahwa pada kombinasi TB yang berlokasi di paru dan ekstra paru akan lebih berisiko 1,74 kali $(95 \% \mathrm{Cl}: 0,47-6,84)$ terhadap kematian. TB yang berlokasi di ekstra paru akan lebih berisiko 1,49 kali (95\% $\mathrm{Cl}$ 0,76-2.91) terhadap kematian dibandingkan dengan lokasi TB di paru 
yang menjadi referen. Namun nilai estimate ini juga tidak signifikan bermakna secara statistik pada derajat kemaknaan 0,05 dengan nilai $p$ masing-masing 0,407 dan 0,241. Hal ini kemungkinan disebabkan karena pengaruh bias informasi dalam dalam mengklasifikasikan kasus TB paru dan ekstra paru yang datanya hanya berasal dari register TB nasional rutin di negara tersebut, dimana disebutkan bahwa dalam mendiagnosis TB paru menggunakan pemeriksaan mikroskopis namun untuk TB ekstra paru seringkali hanya berdasarkan gejala klinis tanpa pemeriksaan lanjutan karena keterbatasan fasilitas ${ }^{11}$.

Penelitian lain mendapatkan hasil yang berbeda dengan penelitian ini, yaitu dengan nilai estimate yang bermakna secara statistik pada derajat kemaknaan 0,05 . Penelitian di Ukraina menyimpulkan bahwa TB ekstra paru merupakan faktor risiko kematian pada pasien ko-infeksi TBHIV dengan hazard rate $2,2(95 \% \mathrm{Cl}: 1,1-$ 8,3). Penelitian tersebut menggunakan subyek penelitian sebanyak 80 orang berasal dari salah satu pusat perawatan AIDS di Ukraina yang diikuti selama 60 bulan masa pengamatan. Diagnosis TB paru ditegakkan dengan pemeriksaan mikroskopis dari sputum atau aspirasi bronkus tanpa pemeriksaan radiologi, sedangkan TB ekstra paru berdasarkan manifestasi klinis yang dibuktikan dengan hasil biopsi yang mendukung setidaknya dari satu di lokasi ekstra paru, baik dengan atau tanpa kombinasi dengan TB paru $^{14}$.

Epidemi HIV berdampak sangat mencolok terhadap prognosis dan kematian TB. HIV merupakan faktor risiko yang paling kuat bagi yang terinfeksi TB untuk menjadi sakit TB $^{10}$. Infeksi HIV mengakibatkan kerusakan sistem imunitas tubuh yang luas sehingga jika terjadi infeksi penyerta (oportunistik) seperti TB akan mengakibatkan penyebaran kuman TB yang meluas seperti ke kelenjar getah bening, pleura dan organ lainnya. TB ekstraparu sering terjadi pada kondisi dimana kekebalan tubuh sangat menurun seperti pada infeksi $\mathrm{HIV}^{23}$.

TB ekstra paru memiliki beban bakteri TB yang lebih tinggi dan menunjukkan rendahnya status imunitas yang parah
(14). Kondisi dimana TB telah menyebar dan menyerang organ selain paru, baik berupa TB ekstra paru saja atau kombinasi TB paru dan ekstra paru menunjukkan progresifitas perjalanan penyakit semakin parah yang mengakibatkan probabilitas ketahanan hidup (kesintasan) penderitanya semakin menurun $^{12}$. WHO pada tahun 2006 merekomendasikan untuk meningkatkan diagnosis TB BTA negatif dan TB ekstra paru karena pada penderita HIV tingkat kematiannya semakin tinggi. Pada pasien yang terinfeksi HIV mungkin memiliki beberapa infeksi bersamaan yang menunjukkan manifestasi klinis yang hampir mirip, sehingga diagnosa klinis yang dikonfirmasi dengan pemeriksaan mikrobiologis lainnya untuk mendiagnosa TB sangat penting dilakukan ${ }^{24}$.

Pada penelitian ini cukup banyak catatan rekam medik yang tidak ditemukan atau tidak lengkap dan merupakan rekam medik pasien in-aktif baik karena telah meninggal atau pindah ke institusi pelayanan lain. Rekam medik tersebut kemungkinan adalah milik sejumlah pasien yang diduga mengalami event. Selain itu data dari rekam medik yang diisi oleh pihak lain di masa lalu, kualitas pengukurannya tidak dapat dikontrol oleh peneliti sehingga kemungkinan pencatatan kurang lengkap dan bias dalam mencatat data serta informasi yang didapatkan bisa saja terjadi, termasuk dalam penemuan dan diagnosa TB berdasarkan lokasi anatomi.

\section{KESIMPULAN}

Kesintasan (probabilitas survival) 2 tahun pasien ko-infeksi TB-HIV setelah diagnosis secara kumulatif (keseluruhan) di RSPI Prof. Dr. Sulianti Saroso Jakarta masih cukup tinggi (>80\%). Kesintasan (probabilitas survival) 2 tahun pasien koinfeksi TB-HIV setelah diagnosis dengan lokasi anatomi TB di ekstra paru lebih rendah dibandingkan dengan lokasi anatomi TB di paru. Pasien ko-infeksi TBHIV dengan lokasi anatomi TB di ekstra paru, dalam waktu 2 tahun memiliki risiko kematian 1,47 kali $(95 \% \mathrm{Cl}: 0,55-3,90)$ dibandingkan dengan lokasi anatomi TB di 
paru, meskipun tidak bermakna secara statistik.

\section{SARAN}

Perlu dilakukan screening lebih intensif terhadap pasien ko-infeksi TB-HIV, untuk menemukan kemungkinan adanya TB di ekstra paru sedini mungkin secara tepat agar dapat diberikan penatalaksanaan yang sesuai dalam rangka meningkatkan kualitas hidup penderitanya.

Dari hasil penelitian ini tidak adanya hubungan antara lokasi anatomi TB terhadap kesintasan 2 tahun pasien koinfeksi TB-HIV setelah diagnosis. Hal ini mungkin disebabkan karena kurangnya sampel penelitian, maka perlu dilakukan penelitian lanjutan dengan jumlah sampel lebih banyak dari beberapa lokasi penelitian (multi center) sehingga diharapkan dapat menemukan dampak sesungguhya dari pengaruh lokasi anatomi TB terhadap kesintasan pasien ko-infeksi TB-HIV setelah diagnosis.

\section{DAFTAR PUSTAKA}

1. WHO. TB HIV Fact Sheets 2014 [Internet]. WHO; 2014 [cited 2014 Feb 23]. Available from: http://www. who.int/tb/challenges/hiv/tbhiv_factsh eet_2014.pdf?ua $=1$

2. WHO. Global Tuberculosis Report 2014. WHO; 2014.

3. Kemenkes RI. Lembar Fakta Booklet Situasi Terkini Kemajuan Pengendalian Tuberkulosis 2014. Jakarta: Kementerian Kesehatan RI; 2014.

4. Kemenkes RI. Petunjuk Teknis Tata Laksana Klinis Ko-Infeksi TB-HIV. Jakarta: Kementerian Kesehatan RI; 2012.

5. Kemenkes RI. Laporan Situasi Perkembangan HIV\&AIDS Di Indonesia Tahun 2014. Kementerian Kesehatan RI; 2014.

6. Kantipong P, Murakami K, Moolphate S, Aung MN, Yamada N. Causes of mortality among tuberculosis and HIV co-infected patients in Chiang Rai, Northern Thailand. HIVAIDS Auckl NZ. 2012;4:159.
7. Kabali C, Mtei L, Brooks DR, Waddell $\mathrm{R}$, Bakari $\mathrm{M}$, Matee $\mathrm{M}$, et al. Increased mortality associated with treated active tuberculosis in HIVinfected adults in Tanzania. Tuberculosis. 2013;93(4):461-6.

8. Meilani M. Pengaruh Koinfeksi Tuberkulosis Terhadap Kesintasan Tiga Tahun Pasien HIV/AIDS Yang Mendapat Terapi ARV Di Rumah Sakit Penyakit Infeksi Prof. Dr. Sulianti Saroso. [Depok]: Universitas Indonesia; 2014.

9. Prado TN do, Caus AL, Marques $M$, Maciel EL, Golub JE, Miranda AE. Epidemiological profile of adult patients with tuberculosis and AIDS in the state of Espírito Santo, Brazil: cross-referencing tuberculosis and AIDS databases. J Bras Pneumol. 2011;37(1):93-9.

10. Domingos MP, Caiaffa WT, Colosimo EA. Mortality, TB/HIV co-infection, and treatment dropout: predictors of tuberculosis prognosis in Recife, Pernambuco State, Brazil. Cad Saúde Pública. 2008;24(4):887-96.

11. Agbor AA, Bigna JJR, Billong SC, Tejiokem MC, Ekali GL, Plottel CS, et al. Factors Associated with Death during Tuberculosis Treatment of Patients Co-Infected with HIV at the Yaoundé Central Hospital, Cameroon: An 8-Year Hospital-Based Retrospective Cohort Study (20062013). PloS One. 2014;9(12): e115211.

12. Kang'Ombe $C T$, Harries $A D$, Ito $K$, Clark T, Nyirenda TE, Aldis W, et al. Long-term outcome in patients registered with tuberculosis in Zomba, Malawi: mortality at 7 years according to initial HIV status and type of TB. Int J Tuberc Lung Dis. 2004;8(7):829-36.

13. Blanc F-X, Sok T, Laureillard D, Borand L, Rekacewicz C, Nerrienet E, et al. Earlier versus later start of antiretroviral therapy in HIV-infected adults with tuberculosis. $\mathrm{N}$ Engl $\mathrm{J}$ Med. 2011;365(16):1471-81.

14. Andreychyn M, Zhyvytsia D, Shkilna M. Effect of Antiretroviral therapy on survival Of HIV/TB-infected patients in Ukraine. Our Dermatol OnlineNasza 
Dermatol Online [Internet]. 2013 [cited 2015 Mar 3];4(2). Available from: http://www.odermatol.com/odermatolo gy/22013doi/ourd.20132.34.pdf

15. Kemenkes RI. Rencana Strategis Rumah Sakit Penyakit Infeksi Prof. Dr. Sulianti Saroso Tahun 2011-2015. Kementerian Kesehatan RI; 2011.

16. RSPI Sulianti Saroso. Laporan Pokja HIV-AIDS (Working Group HIV-AIDS) Rumah Sakit Penyakit Infeksi Prof. Dr. Sulianti Saroso-Jakarta tahun 2013. Jakarta: Rumah Sakit Penyakit Infeksi Prof. Dr. Sulianti Saroso; 2013.

17. Swaminathan S, Narendran G. HIV and tuberculosis in India. J Biosci. 2008;33(4):527-37.

18. Lemeshow S, Hosmer DW, Klar J, Lwanga S. Adequacy Of Sample Size In Health Studies. Chichester: Jhon Wiley\&Sons Ltd.; 1990.

19. Kleinbaum DG, Klein M. Survival Analysis: A Self Learning Text. New York: Springer; 2012.

20. Do Prado TN, Caus AL, Marques M, Maciel EL, Golub JE, Miranda AE. Epidemiological profile of adult patients with tuberculosis and AIDS in the state of Espírito Santo, Brazil: Cross-referencing tuberculosis and AIDS databases. $J$ Bras Pneumol Publicacao Of Soc Bras Pneumol E Tisilogia. 2011 Feb;37(1):93-9.

21. Kemenkes RI. Pedoman Nasional Pengendalian Tuberkulosis. Kementerian Kesehatan RI; 2014.

22. Elwood M. Critical Appraisal of Epidemilogical Studies and Clinical Trials. Oxford: Oxford University Press; 2007.

23. Albert R, Spiro S, Jett J. Ekstrapulmonary Tuberculosis In: Tuberculosis And Disease Caused By Atypical Mycobacteria. 2004;(Clinical Respiratory Medicine).

24. Kingkaew N, Sangtong B, Amnuaiphon $\mathrm{W}$, Jongpaibulpatana $\mathrm{J}$, Mankatittham W, Akksilp S, et al. HIVassociated extrapulmonary tuberculosis in Thailand: epidemiology and risk factors for death. Int J Infect Dis. 2009 Nov 1;13(6):722-9. 